\title{
Systematics of Helioandesia tarregai gen. et sp. nov. (Lepidoptera: Yponomeutoidea: Heliodinidae) from the Andes of Northern Chile
}

\author{
Héctor A. VARGAS \\ Departamento de Recursos Ambientales, Facultad de Ciencias Agronómicas, \\ Universidad de Tarapacá, Arica, Chile. \\ Email: havargas@academicos.uta.cl; lepvargas@gmail.com \\ (1) https://orcid.org/0000-0002-5355-3157 \\ urn:1sid:zoobank.org:author:F33A83F8-60FF-42F3-AA23-D6A7B64CD183
}

\begin{abstract}
The adult stage of Helioandesia tarregai gen. et sp. nov. (Lepidoptera: Yponomeutoidea: Heliodinidae) is described and illustrated from the arid western slopes of the Andes of northern Chile. The larvae of $H$. tarregai gen. et sp. nov. feed as leaf skeletonizers on Mirabilis acuta (Reiche) Heimerl (Nyctaginaceae). The mostly gray forewing of $H$. tarregai gen. et sp. nov., ornamented with strongly bulging metallic spots, resembles that of the representatives of the mainly Nearctic Lithariapteryx Chambers, 1876. However, the latter lacks $\mathrm{CuP}$ in the forewing, has a single bristle in the female frenulum, and lacks a well-developed cornutus. Helioandesia gen. nov. clustered as sister to Neoheliodines Hsu, 2004 in a cladistic analysis, although no synapomorphies were found for this cluster, while Lithariapteryx was sister to Helioandesia gen. nov. + Neoheliodines based on two synapomorphies. The genetic distance between a DNA barcode sequence of $H$. tarregai gen. et sp. nov. and representatives of other genera of Heliodinidae Heinemann, 1877 was $9.0-12.5 \%$ (K2P), and a maximum likelihood analysis based on this molecular marker confirmed the placement of $H$. tarregai gen. et sp. nov. as a member of this micromoth family. This contribution represents the first confirmed record of Heliodinidae for Chile.
\end{abstract}

Keywords. Leaf skeletonizer larva, new genus, new species, South America, taxonomy.

Vargas H.A. 2021. Systematics of Helioandesia tarregai gen. et sp. nov. (Lepidoptera: Yponomeutoidea: Heliodinidae) from the Andes of Northern Chile. European Journal of Taxonomy 731: 117-134. https://doi.org/10.5852/ejt.2021.731.1209

\section{Introduction}

The Heliodinidae Heinemann, 1877 (Lepidoptera: Yponomeutoidea) is a family of metallic-colored mostly diurnal micromoths, whose monophyly has been supported by morphological (Hsu \& Powell 2004) and molecular (Sohn et al. 2013) analyses. Four autapomorphies are recognized for the Heliodinidae: (1) forewing with $\mathrm{M}$ two-branched, (2) female genitalia with apophyses anteriores fused into a medial band, (3) male genitalia with tegumen enormously expanded posteriorly, and (4) dorsal and lateral bristles in the pupa (Hsu \& Powell 2004). Sixty nine species of this family are currently described (van Nieukerken et al. 2011), most of which occur in the New World, while a few occur in the Palearctic and Australian 
regions (Hsu \& Powell 2004). The larvae of Heliodinidae feed externally as leaf skeletonizers or flower feeders, or internally as leaf miners or stem borers (Harrison \& Passoa 1995; Hsu 2002). Larvae of some species can feed on cecidomyiid galls (Walsingham 1897; Hsu \& Powell 2004). The main host plant family of Heliodinidae is Nyctaginaceae, although some species are associated with Aizoaceae Martinov, Araliaceae Juss., Amaranthaceae Juss., Onagraceae L., Phytolaccaceae R.Br., Piperaceae Giseke and Portulacaceae Juss. (Hsu \& Powell 2004).

Although the Neotropics harbor the largest number of described species of Heliodinidae, a great part of their diversity remains unknown (Heppner 1984, 1987; Heppner \& Landry 1994; Becker 1999; Hsu \& Powell 2004; Heppner 2008). There are no confirmed records of species of this family in Chile. Clarke (1967) indicated that Elachista rubella Blanchard, 1852 (Elachistidae), described from Valdivia, southern Chile, "has the fascies of a heliodinid", and also mentioned its resemblance to some species of Phyllocnistis Zeller, 1848 (Gracillariidae Stainton, 1854) in the shape of the two signa of the female genitalia, but did not find other characters in common with species of this genus. Heppner (1984) listed the species under Heliodines Stainton, 1854 (Heliodinidae). However, Hsu \& Powell (2004) excluded E. rubella from the Heliodinidae based on their updated definition of the family. Currently, the species is again recognized as a member of the Elachistidae Bruand, 1851 (Kaila 2019).

Micromoths fulfilling the four autapomorphies of Heliodinidae listed by Hsu \& Powell (2004) were recently reared from leaf skeletonizer larvae collected on a native Nyctaginaceae in the Andes of the northernmost part of Chile. Further examination revealed that these micromoths represent an undescribed species whose morphological peculiarities preclude its inclusion in any of the 13 genera currently recognized in this family of micromoths (Hsu \& Powell 2004). Accordingly, the aim of this study is to provide the corresponding description of a new genus and species of Heliodinidae based on adult morphology, and to assess its phylogenetic relationships using morphological characters and DNA sequences.

\section{Material and methods}

\section{Sampling, rearing and morphological observations}

The sampling site $\left(18^{\circ} 19^{\prime} 45^{\prime \prime} \mathrm{S}, 69^{\circ} 34^{\prime} 56^{\prime \prime} \mathrm{W}\right)$ is at $3400 \mathrm{~m}$ elevation on the western slopes of the Andes of northern Chile, about $1.5 \mathrm{~km}$ northeast of Zapahuira Village, Parinacota Province. The area has a tropical xeric climate, with seasonal rains between December and March (Luebert \& Pliscoff 2006). The vegetation cover is seasonal, with higher levels shortly after the rains (Muñoz \& Bonacic 2006). Leaf skeletonizer larvae were collected on Mirabilis acuta (Reiche) Heimerl (Nyctaginaceae) in April 2018 and March 2019. The collected larvae were placed in plastic vials with leaves of the plant and paper towel at the bottom and brought to the laboratory. The vials were cleaned periodically and fresh leaves of $M$. acuta were provided until the larvae finished feeding. Vials were observed regularly after pupation. One pupa was placed in ethanol $95 \%$ at $-20^{\circ} \mathrm{C}$ until DNA extraction. The adults obtained were mounted, their abdomens were removed, cleared in hot $\mathrm{KOH} 10 \%$ for a few minutes, stained with Eosin Y and Chlorazol black and slide-mounted with Euparal. Images were captured with Sony CyberShot DSC-HX200V and Micropublisher ver. 3.3 RTV-QImaging digital cameras attached to a Leica M125 stereo microscope and an Olympus BX51 optical microscope, respectively. Morphological descriptions follow the terminology of Hsu \& Powell (2004). The distribution map was generated using SimpleMappr (Shorthouse 2010). Specimens will be deposited in the Colección Entomológica de la Universidad de Tarapacá, Arica, Chile (IDEA).

\section{Cladistic analysis}

The phylogenetic relationships of the new taxon were assessed using morphological characters in a cladistic analysis. The morphological characters of the new taxon were coded and included in the 
data matrix provided by Hsu \& Powell (2004). The data matrix and the resulting trees were edited in the software WINCLADA (Nixon 2002). The cladistic analysis was performed using the software NONA ver. 2.0 (Goloboff 1993). The heuristic search for trees was undertaken under equal weighting, hold*100 000, mult*2000 and hold/100, with all characters treated as unordered and non-additive. Node support was assessed with 200 bootstrap replicates.

\section{DNA extraction and analysis}

DNA extraction from one pupa was performed by staff of the Laboratorio de Biología Molecular de Plantas (Universidad de Tarapacá, Arica, Chile) following the procedures described by Huanca-Mamani et al. (2015). Genomic DNA was sent to Macrogen Inc. (Seoul, South Korea) for purification, PCR amplification and sequencing of the DNA barcode fragment with the primers LCO-1490 and HCO2198 (Folmer et al. 1994) and the PCR program described in Escobar-Suárez et al. (2017). DNA barcode sequences of 658 base pair (bp) length of other genera of Heliodinidae were downloaded from BOLD (Ratnasingham \& Hebert 2007). Sequences were aligned with ClustalW, sequence divergence was assessed by the Kimura 2-parameter (K2P) method, and a maximum likelihood (ML) analysis was performed in the software MEGAX (Kumar et al. 2018). Sequences of the families Bedelliidae Meyrick, 1880 and Scythropiidae Friese, 1966 were also downloaded and included as outgroups in the ML analysis following the phylogenetic study of Yponomeutoidea Stephens, 1829 of Sohn et al. (2013). The nucleotide substitution model (GTR $+\mathrm{I})$ was chosen using the lowest value of Bayesian information criterion (BIC). The statistical support of the nodes was assessed by 1000 bootstrap replicates. The Xia test (Xia et al. 2003) was used to assess the presence of phylogenetic signal in the alignment with a substitution saturation analysis in the software DAMBE ver. 7.2.1 (Xia 2018).

\section{Abbreviations for morphological terms used in the text and the figures}

$\begin{array}{ll}1 \mathrm{~A}+2 \mathrm{~A} & =\text { first anal vein plus second anal vein } \\ \mathrm{A} 9 & =\text { ninth abdominal segment of the larva } \\ \mathrm{CuA} 1, \mathrm{CuA} 2 & =\text { first anterior cubital vein, second anterior cubital vein } \\ \mathrm{CuP} & =\text { posterior cubital vein } \\ \mathrm{M} 1, \mathrm{M} 2 & =\text { first medial vein, second medial vein } \\ \mathrm{R} & =\text { radial vein } \\ \mathrm{R} 1 & =\text { first radial vein } \\ \mathrm{Rs} & =\text { veins of radial sector } \\ \mathrm{Sc} & =\text { subcostal vein } \\ \mathrm{SV} & =\text { subventral seta of the larva }\end{array}$

\section{Abbreviations for depositories for the type material}

IDEA = Colección Entomológica de la Universidad de Tarapacá, Arica, Chile

\section{Results}

\section{Cladistic analysis}

The morphological characters were coded for the new genus and species (Table 1) and included in the data matrix of Hsu \& Powell (2004). The strict consensus (Fig. 1) of four most parsimonious trees had length $=85$ steps, consistency index $=52$ and retention index $=75$. The new genus and species was clustered with Neoheliodines Hsu, 2004, although no synapomorphies were found for this clustering. Lithariapteryx Chambers, 1876 was sister to the new genus and species + Neoheliodines based on two synapomorphies. High bootstrap support was obtained only for Heliodinidae (81\%) and Aetole Chambers, 1875 (99\%). 
Table 1. Character states coded for Helioandesia tarregai gen. et sp. nov. included in the data matrix of Hsu \& Powell (2004) for the cladistic analysis.

\begin{tabular}{|c|c|c|}
\hline & Character & State \\
\hline 01 & Forewing veins R4 and R5 & (0) separate \\
\hline 02 & Forewing vein $\mathrm{CuA} 2$ & (0) present \\
\hline 03 & Hindwing vein $\mathrm{CuA} 2$ & (0) presente \\
\hline 04 & Forewing veins $\mathrm{M} 1$ and $\mathrm{M} 2$ & (0) separate \\
\hline 05 & Frenulum of female & $\begin{array}{l}\text { (1) double, asymmetrical, with one bristle shorter than } \\
\text { the other }\end{array}$ \\
\hline 06 & Forewing plane & (0) flat or barely bent at apex \\
\hline 07 & Shape of scaling behind eyes & (0) linear, narrow, long, visible externally \\
\hline 08 & Shape of antenna & (0) cylindrical filiforme \\
\hline 09 & Shape of pleural lobes of A8 in male & (0) weakly sclerotized \\
\hline 10 & Condition of tergum of A8 in male & (0) unmodified \\
\hline 11 & Anterior margin of tergum of $\mathrm{A} 8$ in male & $\begin{array}{l}\text { (1) with a pair of triangular processes extending anterior- } \\
\text { ly beneath A7 }\end{array}$ \\
\hline 12 & Male coremata & $\begin{array}{l}\text { (0) present, forming pouches or shallow depressions } \\
\text { containing scales }\end{array}$ \\
\hline 13 & Length of medial spurs of metatibia & (0) inner spur at least $1.5 \mathrm{X}$ longer than outer one \\
\hline 14 & Hind leg posture & (0) not raised \\
\hline 15 & Form of signum/signa & $\begin{array}{l}\text { (0) not, or shallowly, invaginated, with tiny teeth-like, } \\
\text { sclerotized processes on outer surfasse }\end{array}$ \\
\hline 16 & Position and symmetry of signum/signa & (2) present on one side of corpus bursae only \\
\hline 17 & Texture of signum/signa & $\begin{array}{l}\text { (1) two textures, with the proximal portion coarser than } \\
\text { the distal portion }\end{array}$ \\
\hline 18 & Point of origin of ductus seminalis & (0) on ductus bursae \\
\hline 19 & Appendix bursae & (1) present \\
\hline 20 & $\begin{array}{l}\text { Shape of medial band of ventral branches of apophyses } \\
\text { anteriores }\end{array}$ & (0) broad, triangular or somewhat rectangular \\
\hline 21 & Base of ductus bursae & $\begin{array}{l}\text { (1) heavily sclerotized into a cylinder immediately sub- } \\
\text { tending the ostium bursae }\end{array}$ \\
\hline 22 & Sclerotization of ductus bursae excluding the base & (1) heavy sclerotization on ductus bursae \\
\hline 23 & Structure of dorsal side of tegumen & (0) unmodified \\
\hline 24 & Basal end of tegumen & (0) unmodified \\
\hline 25 & Position of opening of bulbus ejaculatorius on phallobase & (0) basal (anterior) end of phallobase \\
\hline 26 & Upcurved hook at distal tip of aedeagus & (0) absent \\
\hline 27 & External processes near or at distal end of aedeagus & (0) absent \\
\hline 28 & Distal end of saccus & (1) swollen into a spherical club \\
\hline 29 & SV setae on A9 of late instar larva & (1) one seta \\
\hline 30 & Number of lateral bristles on A2 through A7 of pupa & (0) three \\
\hline 31 & Larval feeding behavior. Four states are recognized & (0) external feeding \\
\hline 32 & Head scaling & (1) smooth \\
\hline 33 & Apophyses anteriores ventral branches & (1) fused into a medial band \\
\hline 34 & Pupa dorsal and lateral bristles & (1) present \\
\hline 35 & Tegumen & (1) enormously expanded posteriorly \\
\hline 36 & Forewing $M$ veins & (1) two-branched \\
\hline
\end{tabular}


Table 2. DNA barcode sequences used in the molecular analyses.

\begin{tabular}{lccc}
\hline \multicolumn{1}{c}{ Species } & BOLD accession & GenBank accession & Country \\
\hline Heliodinidae Heinemann, 1877 & & & \\
Aetole extraneella (Walsingham, 1881) & LNEL070-06 & & USA \\
Embola ionis (Clarke, 1952) & BBLPA771-10 & JF841791 & Canada \\
$\begin{array}{l}\text { Epicroesa metallifera Meyrick, 1907 } \\
\text { Helioandesia tarregai } \text { gen. et sp. nov. }\end{array}$ & LTOL953-08 & KF491708 & Taiwan \\
Neoheliodines nygtaginella (Gibson, 1914) & NAMUM309-08 & MT782162 & Chile \\
Bedelliidae Meyrick, 1880 & & & USA \\
Bedellia somnulentella (Zeller, 1847) & AGAKS639-17 & & \\
& & & Canada \\
Scythropiidae Friese, 1966 & & & \\
Scythropia crataegella (Linnaeus, 1767) & FBLMT621-09 & GU706642 & Germany \\
\hline
\end{tabular}

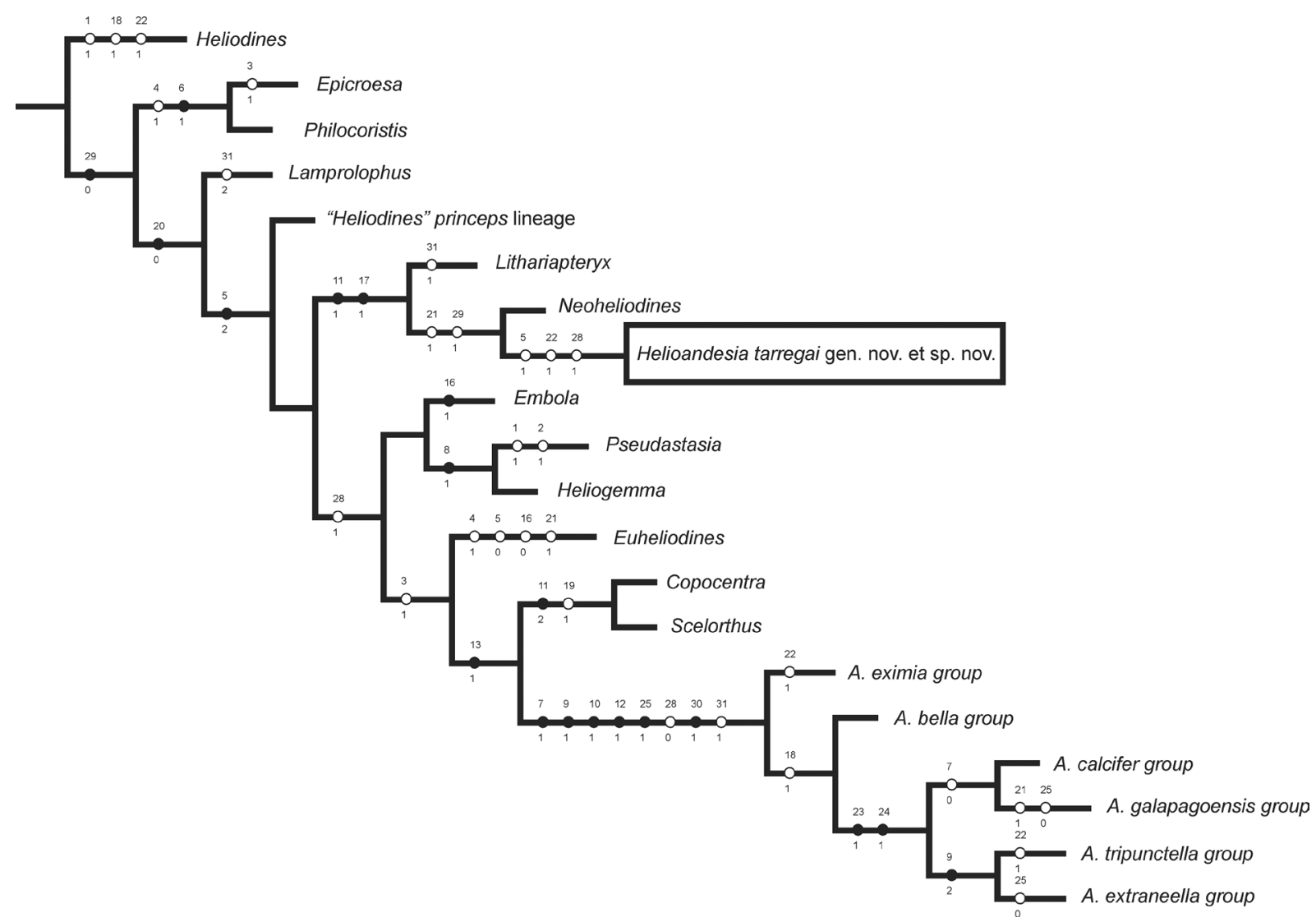

Fig. 1. Strict consensus ( 85 steps, consistency index 52, retention index 75 ) of the four most parsimonious trees, showing the phylogenetic relationships of Helioandesia tarregai gen. et sp. nov. (rectangle) based on the data matrix provided by Hsu \& Powell (2004). Only unambiguous changes are shown. Outgroups not shown. 


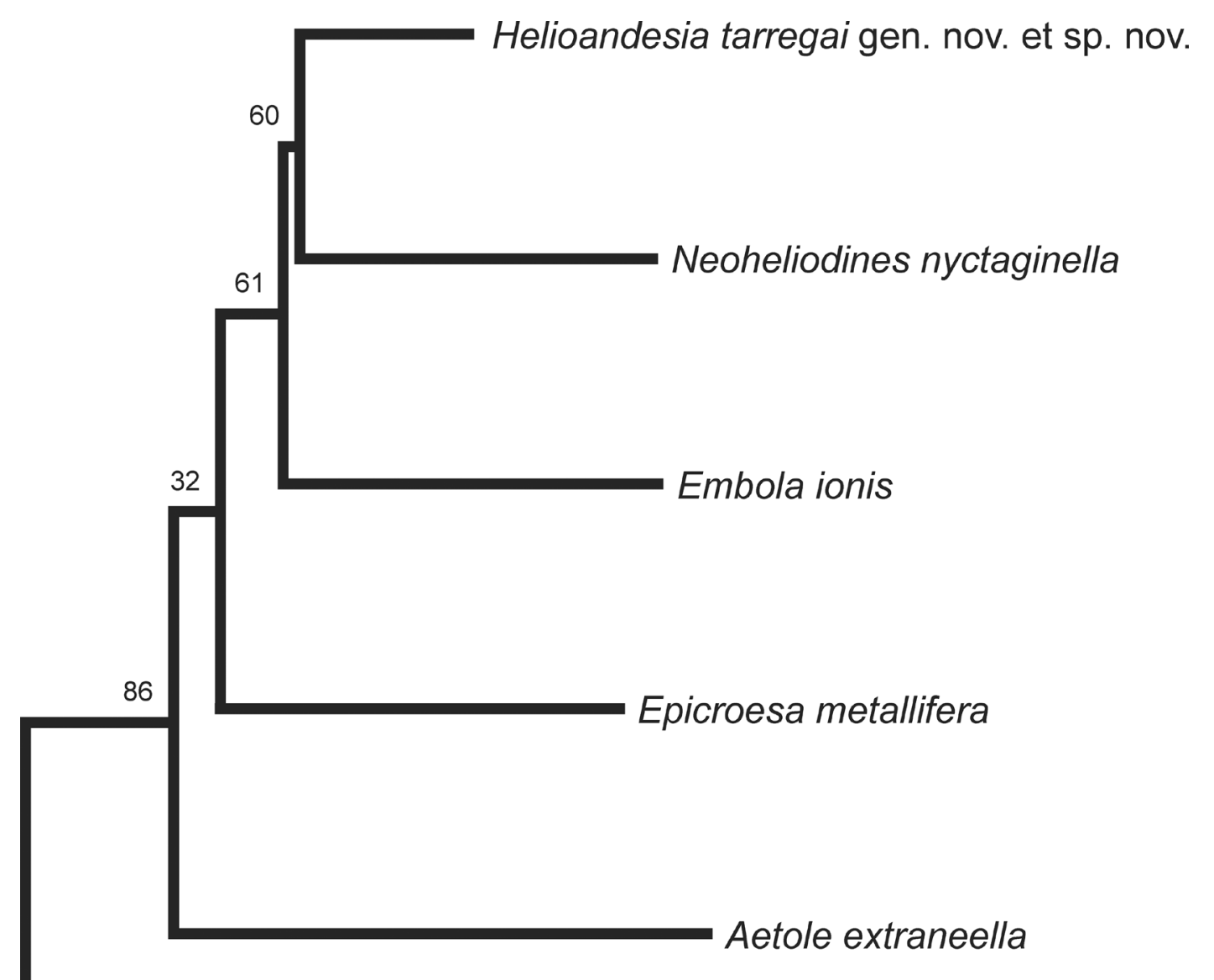

Scythropia crataegella

Bedellia somnulentella

\subsection{0}

Fig. 2. Maximum likelihood tree of DNA barcode haplotypes of Helioandesia tarregai gen. et sp. nov. and other genera of Heliodinidae. Sequences of Bedellia somnulentella (Zeller, 1847) (Bedelliidae Meyrick, 1880) and Scythropia crataegella (Linnaeus, 1767) (Scythropiidae Friese, 1966) were included as outgroups. Numbers indicate bootstrap percentages (1000 replicates). 


\section{DNA barcodes}

Five DNA barcode sequences of Heliodinidae and two of outgroups (Bedelliidae and Scythropidae) were included in the alignment of 657 bp length with 178 variable sites (Table 2). The genetic distance between the new genus and species (GenBank accession MT782162) and other genera of Heliodinidae was $9.0-12.5 \%$ (K2P). No evidence of stop codons and no substitution saturation (ISS $<$ ISS.C; $p<0.001$ ) were detected in the alignment, indicating that the data set was suitable for phylogenetic analysis. The ML analysis confirmed the monophyly of Heliodinidae and the placement of the new genus and species as a member of this family. Furthermore, although with low support, the ML clustered the new genus and species with Neoheliodines nyctaginella (Gibson, 1914), the only representative of Neoheliodines Hsu, 2004 in the alignment (Fig. 2).

\section{Taxonomy}

Class Insecta Linnaeus, 1758

Order Lepidoptera Linnaeus, 1758

Family Heliodinidae Heinemann, 1877

Helioandesia gen. nov.

urn:1sid:zoobank.org:act:2ACDF84E-8E2D-43C6-90D5-B271DC332483

Figs 3-6

\section{Type species}

Helioandesia tarregai gen. et sp. nov., designated here.

\section{Diagnosis}

Helioandesia gen. nov. can be recognized by the following combination of morphological characters: (1) presence of $\mathrm{CuP}$ on forewing of female and male; (2) two bristles of unequal length in the female frenulum; (3) forewing mostly gray, ornamented with strongly bulging metallic spots, (4) two triangular processes on anterior margin of tergum VIII in the male abdomen; (5) sclerotization of the widened proximal part of the ductus bursae not reaching the ostium; (6) signum with proximal portion coarser than distal portion; (7) presence of an appendix bursae; (8) slightly swollen distal end of the saccus; and (9) a well-developed cornutus on the vesica. The mostly gray forewing pattern of Helioandesia gen. nov., ornamented with strongly bulging metallic spots, resembles that of the mainly Nearctic Lithariapteryx. However, the latter lacks $\mathrm{CuP}$ in the forewing of female and male, has a single bristle in the female frenulum, and lacks a well-developed cornutus on the vesica. The female genitalia of H. tarregai gen. et sp. nov. are very similar to those of the Bolivian Lithariapteryx loriculata (Meyrick, 1932) in the shape of the transverse bridge, signum and antrum. However, H. tarregai gen. et sp. nov. lacks a V-shaped mark from costa on the forewing, has a sclerotization on the distal part of the ductus bursae and has the signum on the left margin of the corpus bursae, while L. loriculata has a V-shaped mark from the costa on the forewing, lacks sclerotization on the distal part of the ductus bursae and has the signum on the middle of the ventral part of the corpus bursae. The male of $L$. loriculata remains unknown, impeding comparison with $H$. tarregai gen. et sp. nov. Two bristles of unequal length in the female frenulum of Helioandesia gen. nov. resemble those of Epicroesa Meyrick, 1907, Heliodines, Lamprolophus Busck, 1900 and Philocoristis Meyrick, 1927. However, all these genera lack CuP in the forewing. 


\section{Etymology}

The genus name is derived from the Greek 'helios' (sun), the root of the family name Heliodinidae, and Andes, in reference to the Andes Range, among whose amazing landscapes the type species of Helioandesia gen. nov. was discovered. The name is considered feminine in gender.

\section{Description}

\section{Male}

HEAD. Frons and vertex with appressed scales; narrow, elongated scales behind compound eyes. Antenna filiform, about 0.7 times as long as forewing, basal five segments of flagellum slightly broadened (Fig. 3C) due to narrow superimposed scales on dorsal side. Labial palpus (Fig. 3B) porrect, with appressed scales.
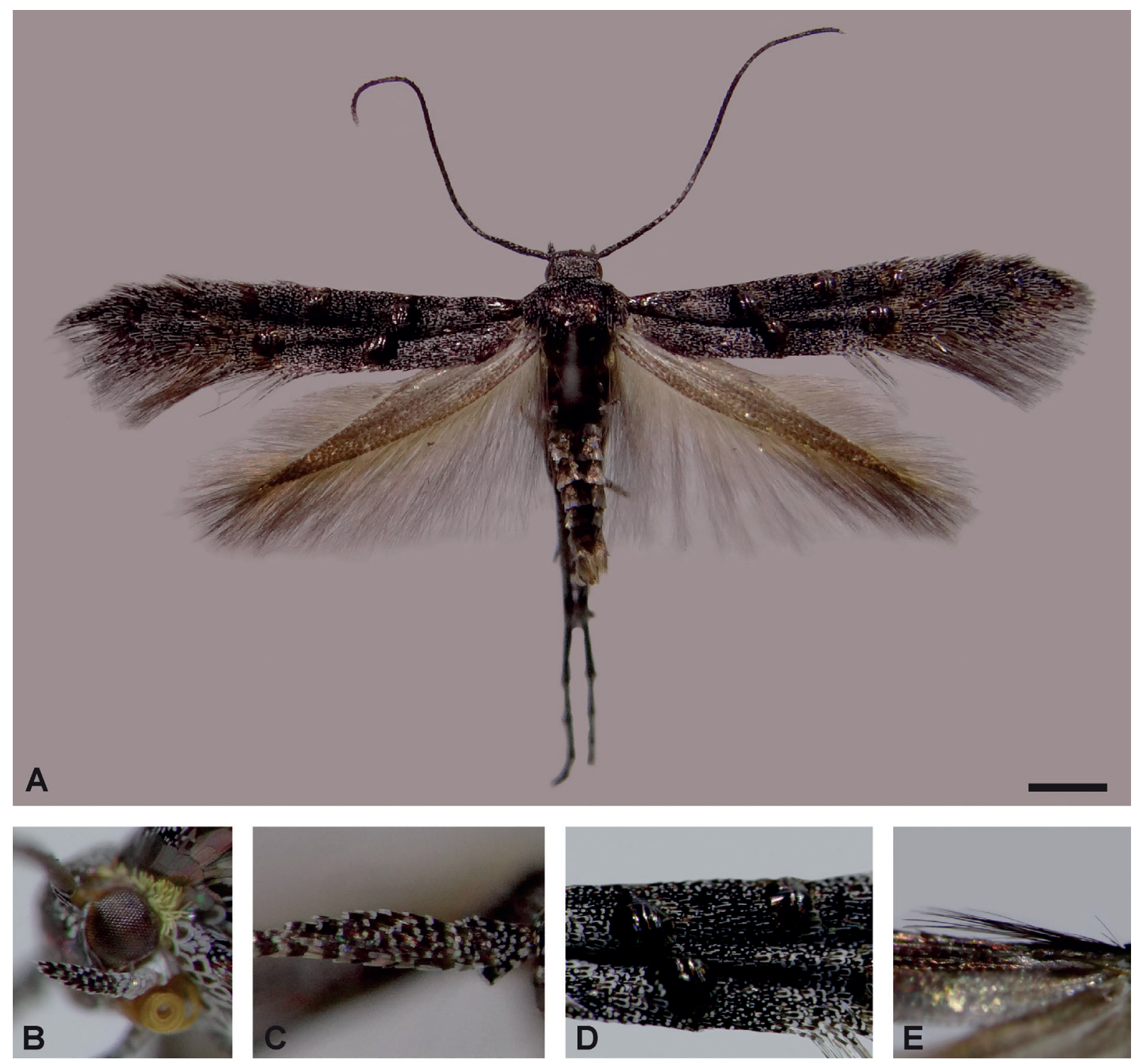

Fig. 3. Helioandesia tarregai gen. et sp. nov., đ̂, holotype (IDEA-LEPI-2020-015). A. Dorsal view. B. Head, lateral. C. Basal flagellomeres of right antenna. D. Three bulging metallic spots on the basal half of forewing. E. Hair pencil from base of subcosta, ventral. Scale bar: $1 \mathrm{~mm}$. 
THORAx. Covered with appressed scales. Tibial spurs 0-2-4; metatibia with inner spur of proximal pair about twice as long as outer one. Forewing lanceolate (Fig. 4), with strongly bulging metallic spots (Fig. 3A, D); hair pencil (Fig. 3E) from base of subcosta ventrally; 12 veins; five R, all separate; M1 and $\mathrm{M} 2$ separate; $\mathrm{CuA} 1$ and $\mathrm{CuA} 2$ separate, proximal part of latter lost; $\mathrm{CuP}$ present as tubular vein near margin; 1A+2A present. Hindwing (Fig. 4) lanceolate, six veins; Sc+R1 and Rs separate; M1 and M2 stalked; $\mathrm{CuA} 1$ and $\mathrm{CuA} 2$ stalked; frenulum a single bristle.

ABdomen. Tergum VIII (Fig. 5C) triangular; anterior margin slightly concave, antero-lateral vertices as small processes slightly extending anteriorly beneath tergum VII; lateral margin widely convex; posterior margin about $1 / 3$ of anterior margin, with wide rounded notch in middle. Pleural lobe (Fig. 5C) triangular, with slightly sclerotized stripe near posterior margin. Sternum VIII not differentiated. Coremata (Fig. $5 \mathrm{G}$ ) between pleural lobes and genitalia.

GENITALIA (Fig. 5). Tegumen posteriorly expanded, somewhat conical, narrowing posteriorly. Gnathos absent. Socius (Fig. 5D) narrow, conical, with hair-like setae, apex coincides with that of tegumen. Saccus narrow, rod-shaped, about twice as long as tegumen, slightly broadened near base, distal end slightly swollen. Valva simple, with a few hair-like setae, costal margin broadly concave, ventral margin broadly convex, apex rounded. Phallus cylindrical, elongated, slightly longer than tegumen + saccus, slightly curved ventrally; vesica with prominent, long spine-like cornutus (Fig. 5B, F) slightly smaller than half of phallus, and group of small spine-like cornuti (Fig. 5E); insertion of ductus ejaculatorius near basal third of phallus.

\section{Female}

Mainly similar to male, but hindwing with two asymmetrical bristles on frenulum (Fig. 4), and abdominal segment VIII not modified as in male.

GENITALIA (Fig. 6). Papillae anales (Fig. 6B) narrow, elongated, slightly sclerotized, with hair-like setae. Posterior apophysis rod-like, about twice as long as papillae anales. Anterior apophysis rod-like, slightly
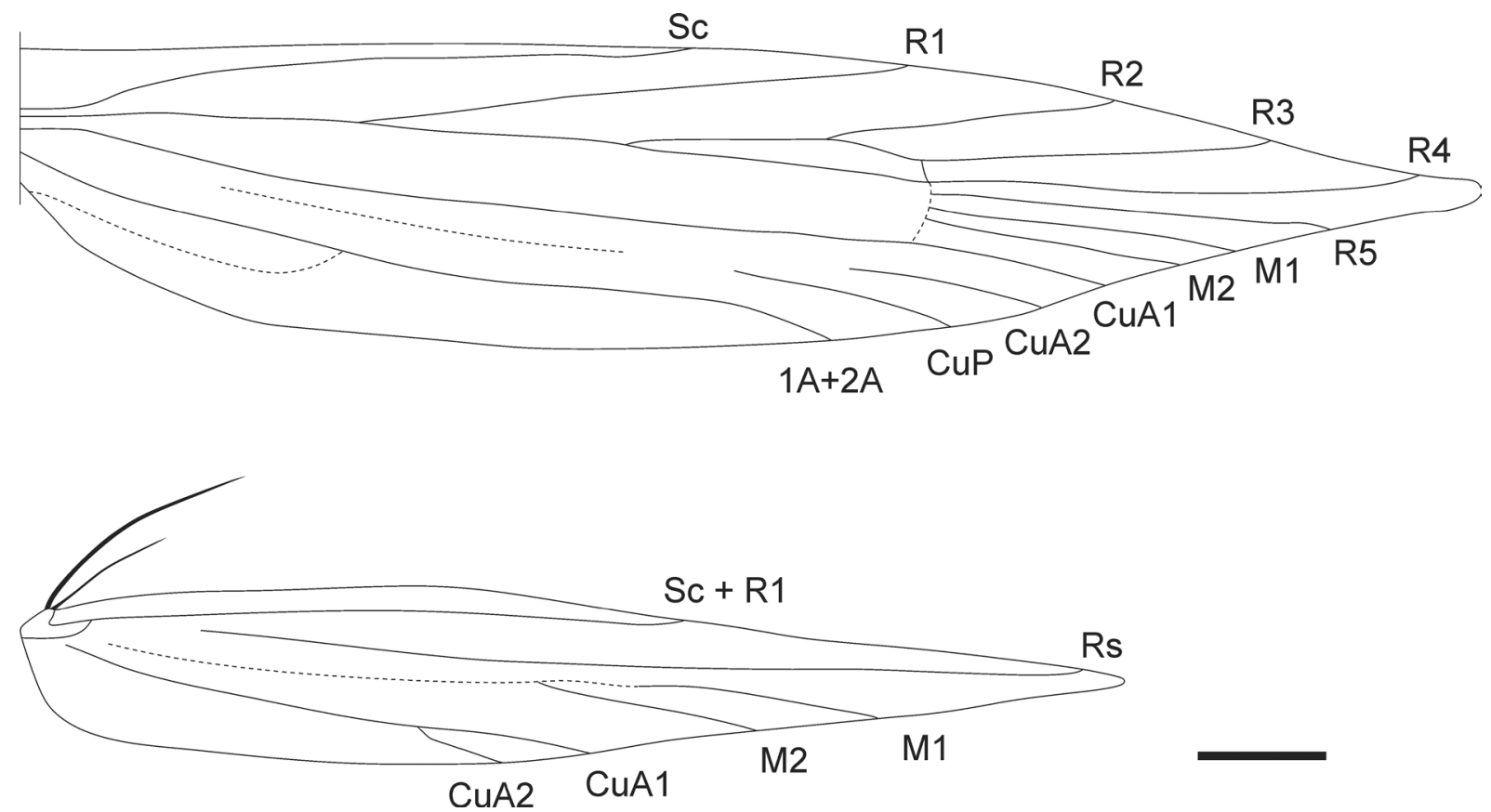

Fig. 4. Helioandesia tarregai gen. et sp. nov., + , paratype (IDEA-LEPI-2020-024), wing venation showing frenulum with two bristles of unequal length. Scale bar: $1 \mathrm{~mm}$. 


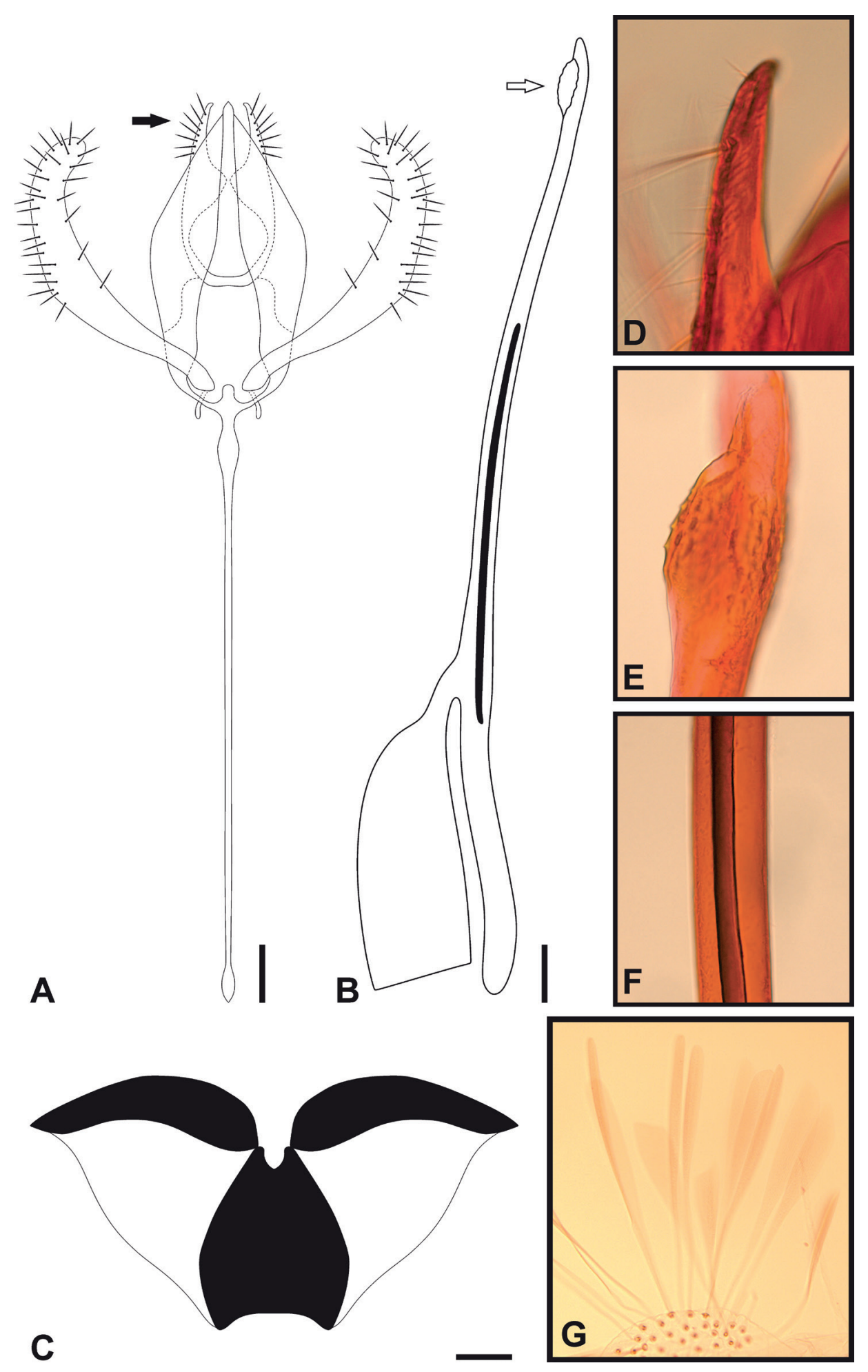

Fig. 5. Male genitalia and eighth segment of Helioandesia tarregai gen. et sp. nov., $\widehat{\jmath}$, paratype (IDEALEPI-2020-021). A. Male genitalia, ventral view, phallus removed. B. Phallus, lateral view. C. Tergum and pleural lobes of eighth segment. D. Socius, closed arrow in A. E. Small spine-like cornuti on the vesica, open arrow in A. F. Medial part of the cornutus. G. Coremata between pleural lobes of segment VIII and genitalia. Scale bars: $0.1 \mathrm{~mm}$. 
shorter than posterior apophysis. Transverse bridge as rectangular transversal band, anterior vertices fused with posterior end of anterior apophyses. Ostium bursae membranous. Ductus bursae narrow, mainly membranous; proximal fourth widened, with distal half sclerotized; slightly widened and sclerotized near corpus bursae. Ductus seminalis arises on distal fourth of ductus bursae. Corpus bursae mainly membranous, lenticular; signum on left side, narrow, elongated, minutely sculptured, proximal (Fig. 6C) portion coarser than distal (Fig. 6D) portion, slightly invaginate and broadened subapically,

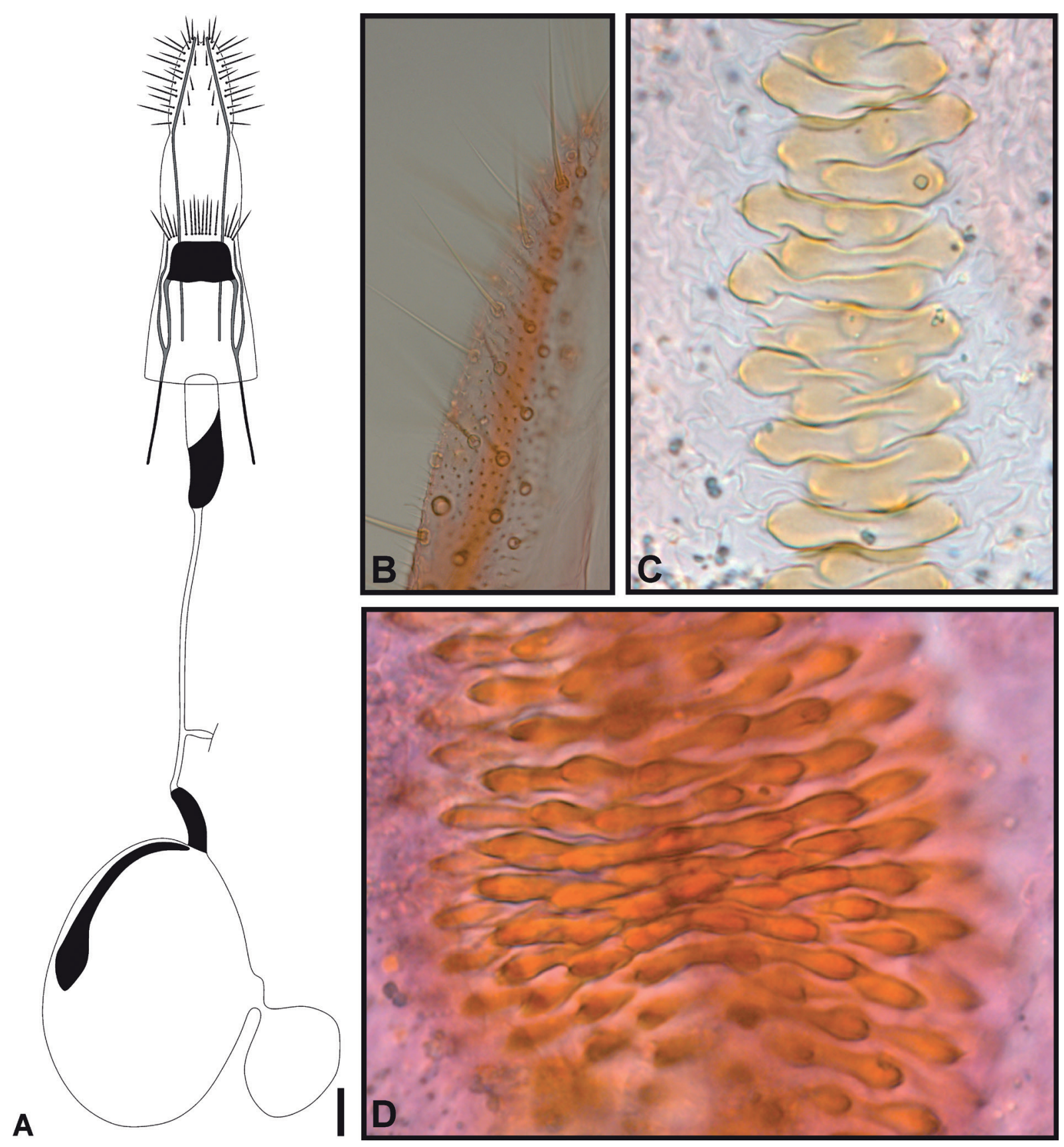

Fig. 6. Female genitalia of Helioandesia tarregai gen. et sp. nov., + , paratype (IDEA-LEPI-2020-024) A. Female genitalia, ventral view. B. Papillae analis. C. Ornamentation of the proximal part of the signum. D. Ornamentation of the distal part of the signum. Scale bar: $0.1 \mathrm{~mm}$. 
length about $2 / 3$ that of corpus bursae. Appendix bursae spherical, membranous, on the middle of corpus bursae, on the opposite side of signum.

Helioandesia tarregai gen. et sp. nov.

urn:lsid:zoobank.org:act:935E51EF-4505-454E-98DA-1FA3156E7ED7

Figs 3-6, Table 1-2

\section{Diagnosis}

As for genus.
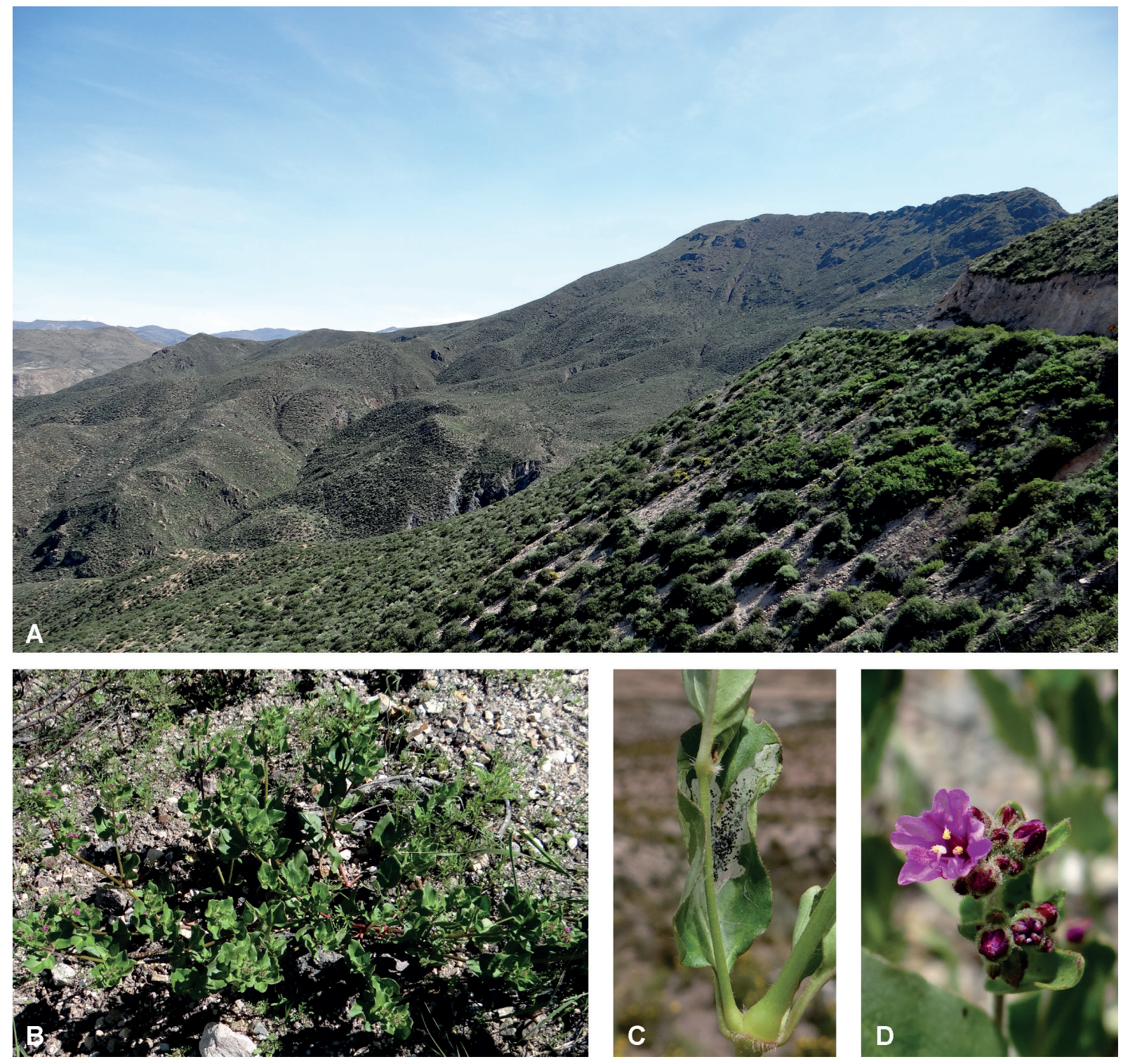

Fig. 7. Habitat and host plant of Helioandesia tarregai gen. et sp. nov. A. The type locality near Zapahuira Village at about $3400 \mathrm{~m}$ elevation on the western slopes of the Andes of the Parinacota Province, northern Chile. B. The host plant Mirabilis acuta (Reiche) Heimerl (Nyctaginaceae). C. Detail of the damage pattern on a leaf of the host. D. Flower of M. acuta. 


\section{Etymology}

Helioandesia tarregai gen. et sp. nov. is named in memory of the eminent Spanish guitarist and composer Francisco Tárrega, for his huge contribution to the repertory of the classical guitar, especially for the wonderful 'Marieta'.

\section{Material examined}

\section{Holotype}

CHILE • O; $^{\prime}$ Parinacota Province, Zapahuira; 18 19'45" S, 69³4'56" W; 3400 m a.s.1.; emerged Apr. 2019; H.A. Vargas leg.; ex-larva, Mirabilis acuta (Reiche) Heimerl; coll. Mar. 2019; "Holotype / Helioandesia / tarregai / Vargas" [red handwritten label]; genitalia slide HAV-1379; IDEA-LEPI-2020-015.

\section{Paratypes}

CHILE - $3 \widehat{\partial} \widehat{\partial}, 2$ 우 ; same collection data as for holotype; IDEA-LEPI-2020-016 to IDEA-

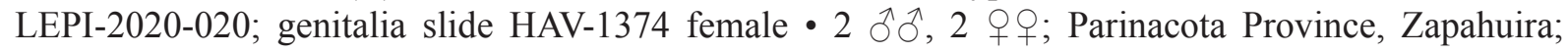
$18^{\circ} 19^{\prime} 45^{\prime \prime} \mathrm{S}$; 69 $34^{\prime} 56^{\prime \prime} \mathrm{W} ; 3400 \mathrm{~m}$ a.s.1.; emerged May 2018; H.A. Vargas leg.; ex-larva Mirabilis acuta (Reiche) Heimerl; coll. Apr. 2018; IDEA-LEPI-2020-021 to IDEA-LEPI-2020-024; genitalia slides HAV-1371 male, HAV-1372 female, HAV-1373 male; IDEA.

\section{Description}

\section{Male}

Forewing length 5.5-6.1 mm. (Fig. 3A-E).

HEAD. Vertex and frons silvery metallic. Pale orange yellow scales behind compound eyes. Antenna with alternate rings of creamy white and brownish gray on basal two third, distal third brownish gray. Labial palpus creamy white on two basal segments; brownish gray scales with creamy white margin on third segment.
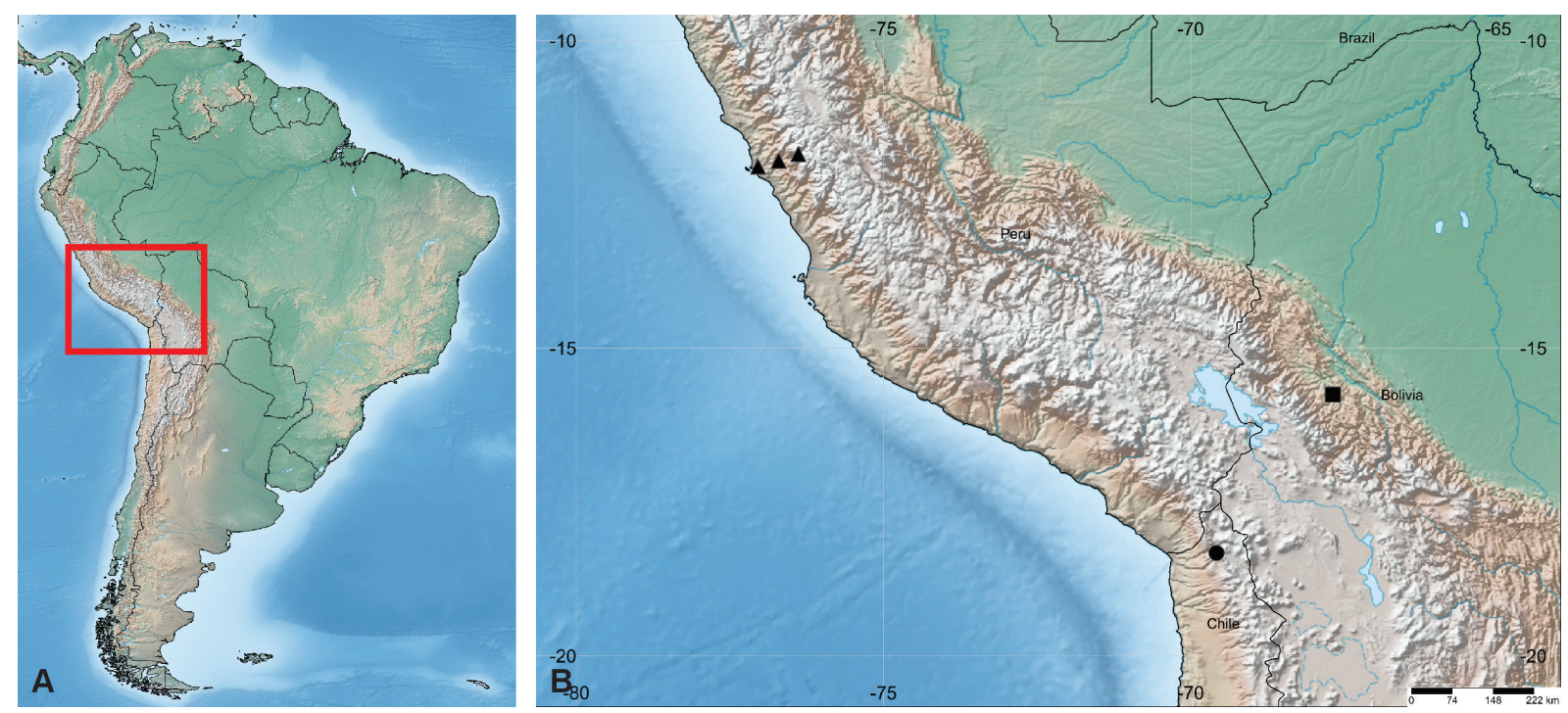

Fig. 8. Geographic distribution of three Neotropical Heliodinidae. Red rectangle on left indicates the location in South America of the area enlarged on right. Circle = type locality of Helioandesia tarregai gen. et sp. nov. in northern Chile. Triangles = distribution of Aetole demarcha (Meyrick, 1917), the geographically nearest heliodinid species to $H$. tarregai gen. et sp. nov. on the western slopes of the Andes, in Peru. Square = type locality of Lithariapteryx loriculata (Meyrick, 1932) on the eastern slopes of the Andes of Bolivia, the morphologically nearest species to H. tarregai gen. et sp. nov. 
THORAX. Variable proportion of silvery metallic and brownish gray with creamy white margin scales dorsally, brownish gray scales with wider creamy white margin latero-ventrally. Legs mainly concolorous with latero-ventral side of thorax. Forewing mostly covered by brownish gray with creamy white margin scales; five metallic silvery bulging spots with black proximal margin, three near costal margin, size progressively decreasing from base to apex, two near anal margin; small metallic silvery spot near tegula, slightly differentiated metallic silvery diagonal stripe from about middle of distal margin of discal cell to near costal margin; a few brownish orange scattered scales mainly on distal half; fringe brownish gray. Hindwing brownish gray; fringe concolorous.

АвDOMEN. Mainly brownish gray dorsally, lighter near posterior margin of each segment; scales brownish gray with creamy white margin ventrally.

GENITALIA (Fig. 5). As described for genus.

\section{Female}

Similar to male.

GENITALIA (Fig. 6). As described for genus.

\section{Host plant}

The only known host plant is the native Mirabilis acuta (Nyctaginaceae) (Fig. 7), a Chilean endemic (Rodríguez et al. 2018). In the study zone M. acuta sprout and flower after the summer rains. The larvae of $H$. tarregai gen. et sp. nov. feed externally as leaf skeletonizers, remaining partially covered by a fine silk layer (Fig. 7C).

\section{Distribution}

Known only from the type locality (Fig. 8), near Zapahuira, Parinacota Province, at about $3400 \mathrm{~m}$ elevation on the western slopes of the Andes of northern Chile.

\section{Discussion}

The taxonomic diversity of Yponomeutoidea has been little explored in the Neotropics in recent years (Cepeda 2016; Vargas 2018; Moreira et al. 2019). Hsu \& Powell (2004) suggested that a great part of the diversity of the Heliodinidae remains unknown in Central and South America. The discovery of $H$. tarregai gen. et sp. nov. supports their suggestion, revealing a previously unknown Neotropical lineage of this micromoth family.

Among the morphological characters of $H$. tarregai gen. et sp. nov., the presence of $\mathrm{CuP}$ in the forewing is remarkable, as its absence or reduction to a vestigial vein was mentioned as a probable autapomorphy for Heliodinidae (Kyrki 1984). However, the placement of $H$. tarregai gen. et sp. nov. in this family, suggested by the presence of the autapomorphies listed by Hsu \& Powell (2004), was confirmed in the cladistic analysis. Since $\mathrm{CuP}$ is either absent or present in the outgroups used in the analysis, an additional heuristic search was undertaken with the character ' $\mathrm{CuP}$ in forewing: (0) absent, (1) present' added to the matrix, but $H$. tarregai gen. et sp. nov. remained as a member of Heliodinidae (not shown).

The presence of two bristles of unequal length in the female frenulum of $H$. tarregai gen. et sp. nov. resembles the basal lineages of Heliodinidae: Epicroesa, Heliodines, Lamprolophus and Philocoristis. However, the cladistic analysis indicated that Helioandesia gen. nov. is only distantly related to these four genera. In contrast, Helioandesia gen. nov. was clustered as sister to Neoheliodines, although this clustering was based on two plesiomorphies: (1) base of ductus bursae heavily sclerotized into a cylinder immediately subtending the ostium bursae (character 21, state 1), and (2) one SV seta on 
A9 of late instar larva (character 29, state 1). The two genera can easily be separated, as the latter lacks $\mathrm{CuP}$ and the strongly bulging metallic spots on the forewing of female and male, has a single bristle in the female frenulum and the ostium bursae surrounded by a sclerotized ring, and lacks a welldeveloped cornutus on the vesica. Two synapomorphies were found for the clustering of (Lithariapteryx (Helioandesia gen. nov. + Neoheliodines)): (1) anterior margin of tergum VIII of the male with a pair of triangular processes extending anteriorly beneath tergum VII (character 11, state 1), and (2) signum with the proximal portion coarser than the distal portion (character 17, state 1). However, the low bootstrap support of this cluster suggests that further studies are needed to understand the phylogenetic relationships of Helioandesia gen. nov. better.

The sclerotization of the widened proximal part of the ductus bursae not touching the ostium appears to be a distinctive character of Helioandesia gen. nov. and could represent an autapomorphy. As shown by Hsu \& Powell (1997), the same state is found in L. loriculata, the only Neotropical representative of the otherwise Nearctic Lithariapteryx, suggesting that this Bolivian species could represent another member of the Helioandesia gen. nov. The remarkable similarity in their genitalia suggests that they could be a pair of cryptic allopatric species separated by the Andes range, with one inhabiting the arid high elevation environments on the western slopes and the other the moist low elevation (type locality $750 \mathrm{~m}$ ) environments on the eastern slopes (Fig. 7). Similar patterns have been described in other families of micromoths (Pereira et al. 2017; Silva et al. 2018). However, as the current knowledge of L. loriculata is based only on the female holotype (Hsu \& Powell 1997), an assessment of the phylogenetic relationships of this species should wait until additional specimens are available for examination and analysis of morphological and molecular characters. In the meantime, Helioandesia gen. nov. is a monotypic genus.

Although the relationships of the genera of Heliodinidae were not well resolved in the ML analysis based on DNA barcode sequences, this analysis was useful to confirm the placement of Helioandesia gen. nov. as a member of this family despite the limited taxon sampling. Additional markers and species of additional genera would be included in further analyses to understand better the phylogenetic relationships of the genera of Heliodinidae using molecular approaches.

The discovery of $H$. tarregai gen. et sp. nov. represents the first confirmed record of Heliodinidae for the Chilean fauna. The nearest records of the family west of the Andes are those of Aetole demarcha (Meyrick, 1917), a little-known species occurring from near sea level to about $2400 \mathrm{~m}$ elevation in the Lima Department, central Peru (Meyrick 1917), about $1000 \mathrm{~km}$ northeast of the type locality of H. tarregai gen. et sp. nov. (Fig. 7). The discovery of H. tarregai gen. et sp. nov. highlights the currently overlooked diversity of micromoths harbored by the arid environments of the Andes that deserves further attention (e.g., Farfán et al. 2020; Vargas et al. 2020). The host plant records of the different genera of Heliodinidae, summarized in detail by Hsu \& Powell (2004), can be used as an extremely valuable guide to explore the Neotropical diversity of this family of micromoths. This approach would be valuable to find immature stages, providing a great opportunity to gain insights on their biology and external morphology, two aspects still little-known in the Heliodinidae of South America.

\section{Acknowledgments}

I would like to thank Yu-Feng Hsu for kind and valuable comments about the taxonomic status of the Chilean specimens of Heliodinidae and for sending photos of the holotype of L. loriculata, Jurate De Prins and two anonymous reviewers for kind comments and suggestions, Mélica Muñoz Schick and Andrés Moreira Muñoz for helpful comments about the host plant, Wilson Huanca-Mamani and Marcelo Vargas-Ortiz for DNA extraction, Sebastián Espinoza-Donoso for editing the figures and Lafayette Eaton for checking the English. 


\section{References}

Becker V.O. 1999. Family reassignments and synonymy of some taxa of Neotropical microlepidoptera. Revista Brasileira de Zoologia 16: 141-170.

Cepeda D.E. 2016. Nueva especie de Kessleria Nowicki, 1864 para Chile central (Lepidoptera: Yponomeutidae) asociada a Maytenus boaria Molina (Celastraceae). Insecta Mundi 0501: 1-6.

Clarke J.F.G. 1967. Neotropical microlepidoptera, XIV. Chilean Microlepidoptera described by Emilio Blanchard. Proceedings of the United States National Museum 122: 1-8.

Escobar-Suárez S., Huanca-Mamani W. \& Vargas H.A. 2017. Genetic divergence of a newly documented population of the cecidogenous micromoth Eugnosta azapaensis Vargas \& Moreira (Lepidoptera: Tortricidae) in the Atacama Desert of northern Chile. Revista Brasileira de Entomologia 61: 266-270. https://doi.org/10.1016/j.rbe.2017.05.004

Farfán J., Cerdeña J., Arivilca M., Condori-Mamani M., Huanca-Mamani W. \& Vargas H.A. 2020. First record of Alucita danunciae (Lepidoptera: Alucitidae) in Peru. Studies on Neotropical Fauna and Environment 55: 103-108. https://doi.org/10.1080/01650521.2019.1702617

Folmer O., Black M., Hoeh W., Lutz R. \& Vrijenhoek R. 1994. DNA primers for amplification of mitochondrial cytochrome c oxidase subunit I from diverse metazoan invertebrates. Molecular Marine Biology and Biotechnology 3: 294-299.

Goloboff P. 1993. NONA. Version 2.0. [Computer software and manual]. Published by the author, Tucumán, Argentina.

Harrison T. \& Passoa S. 1995. Mirabilis-feeding Heliodines (Lepidoptera: Heliodinidae) in central Illinois, with description of a new species. Proceedings of the Entomological Society of Washington 97: $63-70$.

Heppner J.B. 1984. Heliodinidae. In: Heppner J.B. (ed.) Atlas of Neotropical Lepidoptera. Checklist: Part 1, Micropterigoidea-Immoidea: 57. W. Junk, Hague/Boston/Lancaster.

Heppner J.B. 1987. Addendum to Atlas of Neotropical Lepidoptera. Neotropical Lepidoptera News 1: $1-10$.

Heppner J.B. 2008. Sun moths (Lepidoptera: Heliodinidae). In: Capinera J.L. (eds) Encyclopedia of Entomology. Springer, Dordrecht. https://doi.org/c2g8v5

Heppner J.B. \& Landry B. 1994. Anew sun moth from the Galápagos Islands (Lepidoptera: Heliodinidae). Tropical Lepidoptera 5: 126-128.

Hsu Y-F (2002) Larval and pupal biology of a new sun moth in southern California: Novel host use strategy in the evolution of Heliodinidae (Lepidoptera: Yponomeutoidea). Pan-Pacific Entomologist 78: 132-139.

Hsu Y-F. \& Powell J.A. 2004. Phylogenetic relationships within Heliodinidae and systematics of moths formerly assigned to Heliodines Stainton (Lepidoptera: Yponomeutoidea). University of California Publications in Entomology 124: 1-158.

Huanca-Mamani W., Rivera-Cabello D. \& Maita-Maita J. 2015. A simple, fast, and inexpensive CTABPVP-Silica based method for genomic DNA isolation from single, small insect larvae and pupae. Genetics and Molecular Research 14: 7990-8000. https://doi.org/10.4238/2015.July.17.8

Kaila L. 2019. An annotated catalogue of Elachistinae of the World (Lepidoptera: Gelechioidea: Elachistidae). Zootaxa 4632: 001-231. https://doi.org/10.11646/zootaxa.4632.1.1 
Kumar S., Stecher G., Li M., Knyaz C. \& Tamura K. 2018. MEGA X: Molecular Evolutionary Genetics Analysis across computing platforms. Molecular Biology and Evolution 35: 1547-1549.

https://doi.org/10.1093/molbev/msy096

Kyrki J. 1984. The Yponomeutoidea: A reassessment of the superfamily and its suprageneric groups (Lepidoptera). Entomologica Scandinavica 15: 71-84.

Luebert F. \& Pliscoff P. 2006. Sinopsis Bioclimática y Vegetacional de Chile. Editorial Universitaria, Santiago.

Meyrick E. 1917. Heliodinidae. Exotic Microlepidoptera 2: 61-66.

Moreira G.R.P., Brito R., Isaias R.M.S., Silveira J.L. \& Gonçalves G.L. 2019. A redescription of Antispastis clarkei Pastrana (Lepidoptera, Glyphipterigidae) immature stages, with notes on the life history and phylogenetic placement of the genus. Revista Brasileira de Entomologia 63: 183-194. https://doi.org/10.1016/j.rbe.2019.03.001

Muñoz A.E. \& Bonacic C. 2006. Variación estacional de la flora y vegetación en la precordillera andina de la comuna de Putre (I Región de Tarapacá, Chile) durante el período 2002-2003. Gayana Botánica 63: 75-92.

Van Nieukerken E.J., Kaila L., Kitching I.J., Kristensen N.P., Lees D.C., Minet J., Mitter C., Mutanen M., Regier J.C., Simonsen T.J., Wahlberg N., Yen S-H., Zahiri R., Adamski D., Baixeras J., Bartsch D., Bengtsson B.Å., Brown J.W., Bucheli S.R., Davis D.R., De Prins J., De Prins W., Epstein M.E., GentiliPoole P., Gielis C., Hättenschwiler P., Hausmann A., Holloway J.D., Kallies A., Karsholt O., Kawahara A.Y., Koster S., Kozlov M.V., Lafontaine J.D., Lamas G., Landry J-F., Lee S., Nuss M., Park K-T., Penz C., Rota J., Schintlmeister A., Schmidt B.C., Sohn J-C., Solis M.A., Tarmann G.M., Warren A.D., Weller S., Yakovlev R.V., Zolotuhin V.V. \& Zwick A. 2011. Order Lepidoptera Linnaeus, 1758. In: Zhang Z-Q. (ed.) Animal Biodiversity: An Outline of higher-level Classification and Survey of Taxonomic Richness. Zootaxa 3148: 212-221.

Nixon K.C. 2002. Winclada. Ver. 1.00.08. [Computer software and manual]. Published by the author, Ithaca/New York.

Pereira C.M., Silva D.S., Gonçalves G.L., Vargas H.A. \& Moreira G.R.P. 2017. A new species of Leurocephala Davis \& Mc Kay (Lepidoptera, Gracillariidae) from the Azapa Valley, northern Chilean Atacama Desert, with notes on life-history. Revista Brasileira de Entomologia 61: 6-15.

https://doi.org/10.1016/j.rbe.2016.11.003

Ratnasingham S. \& Hebert P.D.N. 2007. BOLD: the barcode of life data system. Molecular Ecology Notes 7: 355-367. Available from http://www.barcodinglife.org [accessed 18 Dec. 2020]. https://doi.org/cv9qqw

Rodriguez R., Marticorena C., Alarcón D., Baeza C., Cavieres L., Finot V.L., Fuentes N., Kiessling A., Mihoc M., Pauchard A., Ruiz E., Sanchez P. \& Marticorena A. 2018. Catálogo de las plantas vasculares de Chile. Gayana Botánica 75: 1-430.

Shorthouse D.P. 2010. SimpleMappr, an online tool to produce publication-quality point maps. Available from https://www.simplemappr.net [accessed 13 Jul. 2020].

Silva G.T., Moreira G.R.P., Vargas H.A., Gonçalves G.L., Mainardi M.D., Blas G.S. \& Davis D. 2018. Overlooked gall-inducing moths revisited, with the description of Andescecidium parrai gen. et sp. n. and Oliera saizi sp. n. from Chile (Lepidoptera, Cecidosidae). ZooKeys 795: 127-157.

https://doi.org/10.3897/zookeys.795.27070 
Sohn J-C., Regier J.C., Mitter C., Davis D., Landry J-F., Zwick A. \& Cummings M.P. 2013. A molecular phylogeny for Yponomeutoidea (Insecta, Lepidoptera, Ditrysia) and its implications for classification, biogeography and the evolution of host plant use. PLOS ONE 8 (1): e55066. https://doi.org/fn23

Vargas H.A. 2018. A new species of Ypsolopha Latreille (Lepidoptera, Ypsolophidae) from the Andes of northern Chile. Nota Lepidopterologica 41: 199-205. https://doi.org/10.3897/n1.41.28570

Vargas H.A., Vargas-Ortiz M. \& Cees G. 2020. A new species of Stenoptilia Hübner (Lepidoptera: Pterophoridae) associated with Neobartsia peruviana (Orobanchaceae) in the Andes of northern Chile. Revista Brasileira de Entomologia 64 (2): e20190028. https://doi.org/fnvg

Walsingham T.G. 1897. Revision of the West-Indian Micro-Lepidoptera, with descriptions of new species. Proceedings of the Zoological Society of London 54-183.

Xia X. 2018. DAMBE7: New and improved tools for data analysis in molecular biology and evolution. Molecular Biology and Evolution 35: 1550-1552. https://doi.org/10.1093/molbev/msy073

Xia X., Xie Z., Salemi M., Chen L. \& Wang Y. 2003. An index of substitution saturation and its application. Molecular Phylogenetics and Evolution 26: 1-7. https://doi.org/chdxt5

Manuscript received: 22 July 2020

Manuscript accepted: 9 November 2020

Published on: 20 January 2021

Topic editor: Nesrine Akkari

Section editor: Jurate de Prins

Desk editor: Eva-Maria Levermann

Printed versions of all papers are also deposited in the libraries of the institutes that are members of the EJT consortium: Muséum national d'histoire naturelle, Paris, France; Meise Botanic Garden, Belgium; Royal Museum for Central Africa, Tervuren, Belgium; Royal Belgian Institute of Natural Sciences, Brussels, Belgium; Natural History Museum of Denmark, Copenhagen, Denmark; Naturalis Biodiversity Center, Leiden, the Netherlands; Museo Nacional de Ciencias Naturales-CSIC, Madrid, Spain; Real Jardín Botánico de Madrid CSIC, Spain; Zoological Research Museum Alexander Koenig, Bonn, Germany; National Museum, Prague, Czech Republic. 